\title{
Clustering of Rice (Oryza sativa L.) Varieties Cultivated in Jaffna District of Sri Lanka based on Salt Tolerance during Germination and Seedling Stages
}

\author{
L. Pradheeban ${ }^{*}$, N.A.A.S.P. Nissanka ${ }^{1}$ and L.D.B. Suriyagoda ${ }^{1}$ \\ Postgraduate Institute of Agriculture \\ University of Peradeniya \\ Sri Lanka
}

\begin{abstract}
Twenty three rice (Oryza sativa L.) varieties cultivated in Jaffna district of Sri Lanka were screened for salt tolerance at the germination and early seedling stage using different salinity levels $\left(0,4,8,12,24\right.$ and $\left.45 \mathrm{dSm}{ }^{-}\right)$. Cluster analysis was done for germination energy, speed of germination, final germination percentage, root length, root dry weight, plumule length and plumule dry weight. All the tested variables, except sodium concentration in grains, decreased with increased salt levels and had significant differences $(p<0.05)$ among the varieties at EC level of $24 \mathrm{dSm}^{-1}$. The osmotic effect and toxic effect due to sodium, in combination, played a major role in germination of seeds and early seedling growth due to inhibitory effect in absorption of water. Among the cultivated rice varieties in Jaffna, Pachchaperumal, At 362, Bg 250, Bg 352, H4, Bg 304, Bg 360 and CO 10 have higher germination energy, speed of germination, final germination percentage, average root length, plumule length and low sodium concentration in grains and were categorized into high tolerant group. The rice varieties At 353 and Addakari were in the tolerant group. Varieties Morungan, Periavellai, At 308 and Moddaikarupan were grouped under the salt sensitive group whereas varieties At 402 and At 303 were in highly sensitive group to salt at $24 \mathrm{dSm}^{-1}$ during their germination stage.
\end{abstract}

Keywords: Germination, Jaffna, rice, salt tolerance, seedling growth

\section{INTRODUCTION}

Rice (Oryza sativa L.) is the staple food for people in Sri Lanka. The annual population growth in Sri Lanka was reported to be at $1.04 \%$ in 2011 (World Bank Report, 2012). Rice production has to be increased further to feed the growing population and the most viable approach of increasing rice production is through the increase of productivity rather than expanding the area cultivated.

Abiotic stresses are the major threat to crop production worldwide, reducing average yields of major crops by more than $50 \%$ (Boyer, 1982). Soil salinity defined as the presences of excess amounts of salts in the soil solution in agricultural lands and it is one of the major obstacles in increasing production in rice growing areas worldwide, which is the ever-present threat to improve crop yield. Therefore, development of salt tolerant varieties is considered as one of the major strategies to increase rice production in saline prone coastal areas.

\footnotetext{
Department of Crop Science, Faculty of Agriculture, University of Peradeniya, Sri Lanka

Corresponding author: loha_p@yahoo.com
} 
Salinity can be developed through natural or human induced processes. The large extent of rice lands in the coastal areas as well as in major irrigation schemes in Sri Lanka have become unproductive due to high salinity (Handawela, 1982). Sirisena \& Herath (2009) stated that salinity is gradually spreading in rice lands of Sri Lanka both in coastal and inland regions.

Jaffna is situated in northern part of the Dry Zone of Sri Lanka. Out of 12,000 ha of cultivated rice land in Jaffna, about 3,000 ha of rice lands are unproductive due to salinity (Rajadurai, 2003). Salt concentrations in the paddy lands of Jaffna fluctuate between soil profile during dry and wet seasons. It is in the range of 16 to $26 \mathrm{dSm}^{-1}$ during dry and 2 to 8 $\mathrm{dSm}^{-1}$ in wet season in top soil (from analysis). Therefore, selection of rice varieties which are tolerant to salinity and suitable to Jaffna climatic conditions with consumer preference is a very urgent need.

Germination is a crucial stage in the life of many plants and salt tolerance during this phase is important for its establishment (Maranon et al., 1989). Under saline conditions, germination ability of one crop differs to another and even varied among different varieties of the same crop. Moreover, for many plants, salt stress is a major inhibitor during seed germination than at any other growth stages. Heenan et al., (1988) reported that rice is extremely sensitive to salinity during germination, young seedling and early developmental stages. Salinity may affect seed germination in two ways: osmotically, by decreasing the ease with which seeds may take up water; and ionically, by facilitating the uptake of ions in excess amounts which would be harmful for the embryonic activities. According to the classification of crop tolerance to salinity, rice crop is within the sensitive group having EC range from 0 to $8 \mathrm{dSm}^{-1}$ (Maas, 1986). For most rice varieties, the susceptibility to salinity stress varies with growth stages.

Various screening methods have developed to differentiate salinity tolerance in rice at different growth stages under field and greenhouse conditions (IRRI, 1989; Chowdhury \& Bowling, 1995). Screening under field conditions is difficult due to stress heterogeneity, significant variation of environmental factors such as temperature, relative humidity, solar radiation and presences of other soil related stresses during the growth period. In addition, these methods are time consuming when screening large number of varieties. Therefore, screening of varieties at early growth stages under laboratory condition is an efficient method to select large number of varieties, which are tolerant to salt stress. However, characters responsible for varietal variation in seed germination and seedling establishment of different rice varieties under saline conditions are not well understood, particularly for rice varieties cultivated in Jaffna. Even though different screening methods (Abeysiriwardena, 2004; Dissanayake \& Wijeratne, 2006; Subashighe et al., 2007) are used in Sri Lanka at germination stage, seed characteristics such as speed of germination and germination energy, and seedling characteristics such as plumule (coleoptile) length and root length were not considered. Therefore, this study was conducted to screen and classify commonly cultivated rice varieties in Jaffna by investigating the variation of seed characteristics, salt tolerant pattern in seeds which influence on seed germination and growth of seedlings.

\section{METHODOLOGY}

The experiment was carried out in the laboratory of Department of Crop Science, Faculty of Agriculture, University of Peradeniya during the period from January to May 2013. Seeds of twenty three rice varieties; seventeen varieties representing commonly cultivated varieties in 
Jaffna (new improved, old improved, traditional or local), two check varieties, three varieties commonly grown in other parts of Sri Lanka and one recently released salt tolerant variety (Bg 369) were selected (Table 1).

Table 1. Selected rice varieties and their types.

\begin{tabular}{ll}
\hline \multicolumn{1}{c}{ Type } & \multicolumn{1}{c}{ Varieties } \\
New improved & Bg 250, At 303, At 353, At 362, At 308, Bg 352, Bg 360, \\
& Bg 406, Bg 304, At 402, Bg 369, Bg 400-1, At 401, Bg \\
& 450 \\
Old improved & H4 \\
Traditional/Local & Modaikarupan, Periavellai, Morungan, Pachchaperumal \\
Check variety & Pokkali, At 354 \\
Other & CO 10, Adakari \\
\hline
\end{tabular}

Paddy seeds were collected from Paranthan (traditional varieties in the region of Jaffna), Rice Research Development Institute, Batalagoda (for check and other varieties) and Plant Genetic Resource Centre, Gannoruwa, Sri Lanka. Germination percentage of each variety was tested before the experiment and germination percentage of all the tested varieties was over $85 \%$ (Table 2).

Table 2. Germination percentages of tested varieties.

\begin{tabular}{lclclc}
\hline Variety & $\begin{array}{c}\text { Germination } \\
\text { percentage }\end{array}$ & Variety & $\begin{array}{c}\text { Germination } \\
\text { percentage }\end{array}$ & Variety & $\begin{array}{c}\text { Germination } \\
\text { percentage }\end{array}$ \\
Pokkali & 98 & At 353 & 94 & Modaikaruppan & 90 \\
Bg 250 & 98 & At 362 & 96 & Periavellai & 94 \\
Bg 406 & 98 & At 402 & 92 & Morungan & 100 \\
Bg 352 & 94 & At 308 & 98 & Pachchaperumal & 98 \\
At 303 & 100 & Bg 369 & 100 & Adakari & 98 \\
H4 & 100 & Bg 400-1 & 86 & Bg 360 & 90 \\
CO 10 & 98 & Bg 450 & 98 & Bg 304 & 86 \\
At 401 & 90 & At 354 & 90 & & \\
\hline
\end{tabular}

Healthy, vigorous and uniform size seeds were selected from all the tested varieties and surface sterilized with $5 \%$ sodium hypochlorite solution for five minutes. Then seeds were thoroughly washed by distilled water and dried using tissue paper. Twenty (20) surface sterilized seeds of each variety were placed in Petri dish of $9 \mathrm{~cm}$ diameter lined with a piece of filter paper. Sodium chloride was used to prepare salt solution because it is safe to use without causing any precipitation of different ions. Each filter paper was moistened with different salt solution $(\mathrm{NaCl})$ concentrations; 4, 8, 12, 24 and $45 \mathrm{dSm}^{-1}$, and distilled water was used as the control $\left(0 \mathrm{dSm}^{-1}\right)$. These concentrations were used in the experiment as rice varieties grown in Jaffna experience salt concentrations in the range of 16 to $26 \mathrm{dSm}^{-1}$ during the dry season and theupper limit used to check salt tolerance is $45 \mathrm{dSm}^{-1}$. Ten millilitres of respective salt solutions was applied to each petri dish.

Treatments were arranged in a completely randomized design (CRD) with four replicates. During the study period, room temperature was $28 \pm 1^{\circ} \mathrm{C}$ with 12 hours photoperiod. The 
number of seeds sprouted and germinated from each petri dish was counted daily up to nine days. Seeds were considered to have germinated when shoot extended to more than $2 \mathrm{~mm}$ from the seed. To check the sodium absorption pattern of seeds, all the tested varieties were soaked for nine days separately in same concentrations of salt solutions. The experiment was repeated twice to determine the consistency of results of varieties tested against different salt solution concentrations.

\section{Measurements}

At the ninth day, plumule length of germinated seedlings was measured from ten randomly selected samples of each replicate per treatment. Average root (radicle) length was calculated using WinRhizo software. Shoot and root dry weights were measured after oven drying at 70 ${ }^{\circ} \mathrm{C}$ for 3 days. Sodium concentration in none germinated grains and in husk in different salt solutions was measured by using flame photometer.

\section{Calculations}

Germination Energy (GE), Speed of Germination (SG) and Final Germination Percentage (FGP) were calculated by using the following formulas (Ruan et al., 2002).

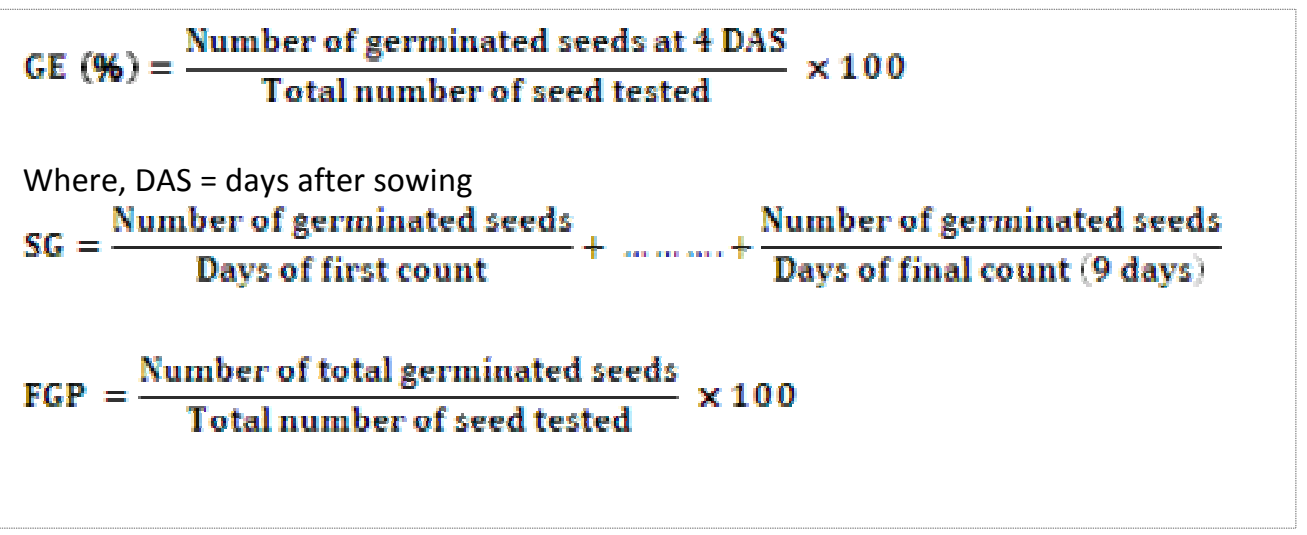

\section{Data Analysis}

\section{Cluster Analysis}

To prepare the dendogram, speed of germination, germination energy, final germination percentage, root length, root dry weight, plumule length and plumule dry weight were considered. Cluster analysis was done in SAS 9.1 version using the Proc CLUSTER procedure. Multivariate analysis of variance (MANOVA) was used to determine whether different clusters identified through cluster analysis were significantly different or not using the test statistic, Wilks' Lambda.

\section{Analysis of Variance}

To check the difference between the varieties within each cluster for germination energy, speed of germination, final germination percentage and plumule length; an analysis of 
variance was performed using Proc GLM procedure followed by the LSMEANS procedure for mean separation. All the significances were expressed at $\alpha=0.05$.

\section{Correlation Analysis}

The correlation analysis between variables GE, SG, FGP, ARL and APL was done at the EC level of $24 \mathrm{dSm}^{-1}$.

\section{RESULTS AND DISCUSSION}

For all the varieties none of the seeds were germinated under the salt level of $45 \mathrm{dSm}^{-1}$. Speed of germination, germination energy, final germination percentage, root length, root dry weight, plumule length and plumule dry weights were decreased with increase in salt concentration. However, a drastic reduction was observed at high salt level of $24 \mathrm{dSm}^{-1}$. This level was taken as the upper limit for the analysis and results were presented. Grouping of varieties were needed for screening and selection. Results from cluster analysis showed clear grouping at EC level of $24 \mathrm{dSm}^{-1}$ (Fig. 1).

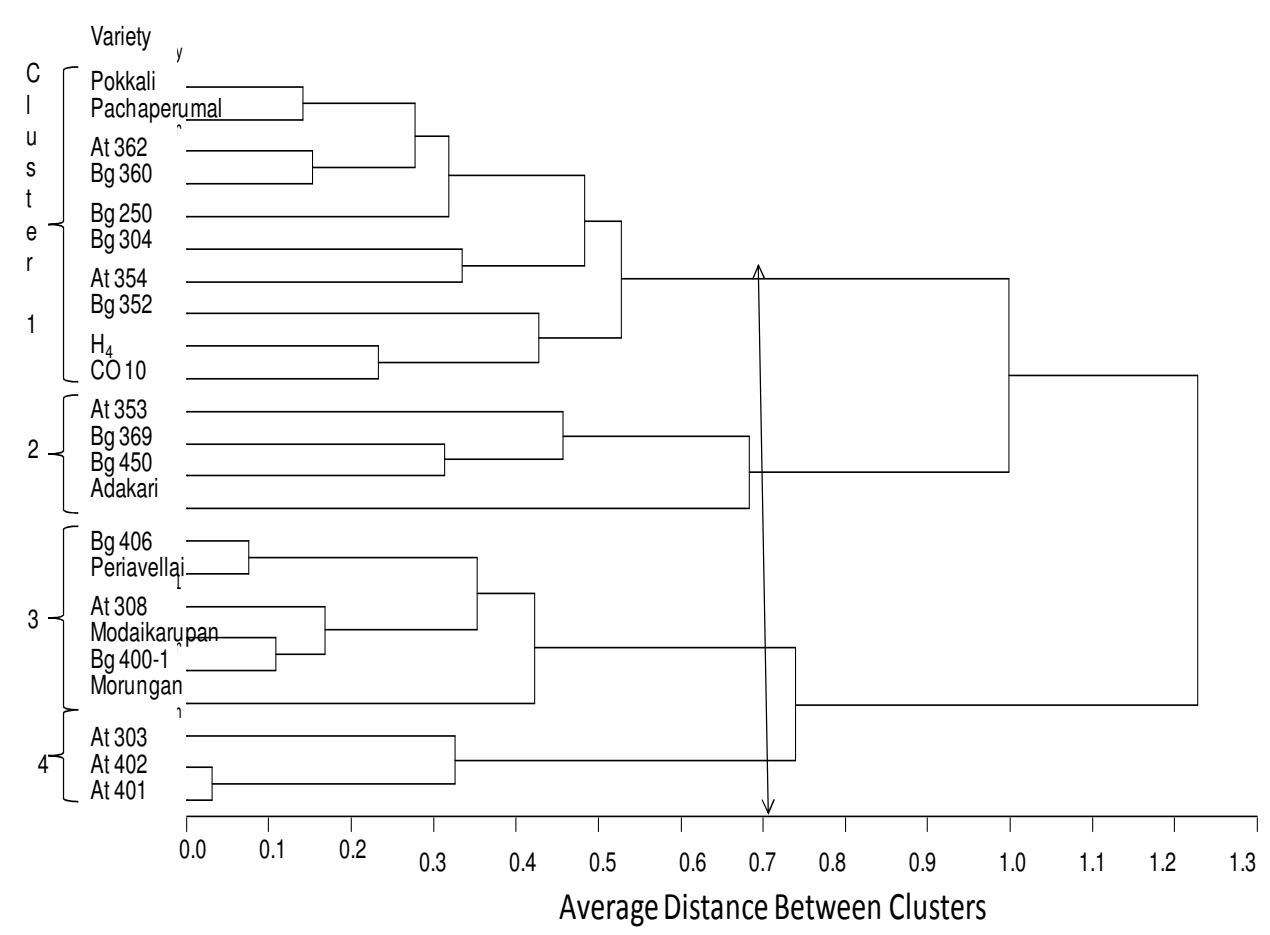

\section{Fig. 1. Dendogram of varieties at EC level of $24 \mathrm{dSm}^{-1}$.}

Clustering was done at a standardized distance of 0.7 in the dendogram and four distinct clusters were identified as follows. Varieties Pokkali and At 354 grouped together into the first cluster (highly tolerant).

Cluster 1 - Highly tolerant to salt (HT). 
Cluster 2 - Tolerant to salt (T).

Cluster 3 - Susceptible to salt (S).

Cluster 4 - Very susceptible to salt (VS).

Based on the dendogram, varieties grouped under different clusters were given in Table 3.

Table 3. Varieties grouped under different clusters.

\begin{tabular}{ll}
\hline Cluster & Varieties \\
$1(\mathrm{HT})$ & Pokkali, Pachchaperumal, At 362, Bg 360, Bg 250, Bg 304, At 354, \\
& Bg 352, H4, CO 10 \\
$2(\mathrm{~T})$ & Bg 369, Bg 450, At 353, Adakari \\
$3(\mathrm{~S})$ & Bg 406, Periavellai, At 308, Modaikarupan, Bg 400-1, Morungan \\
$4(\mathrm{VS})$ & At 303, At 402, At 401 \\
\hline
\end{tabular}

Varieties Pokkali, Pachchaperumal, At 362, Bg 360, Bg 250, Bg 304, At 354, Bg 352, H4, CO 10 were grouped together (high tolerance) because of having the highest speed of germination, germination energy, final germination percentage, average root length and average coleoptiles length. Similarly, varieties At 303, At 402 and At 401 were grouped under very sensitive category due to lowest speed of germination, germination energy, final germination percentage, average root length and average coleoptiles length.

Among the clusters, there were significant differences in germination energy, speed of germination and final germination percentage (Fig. 2).

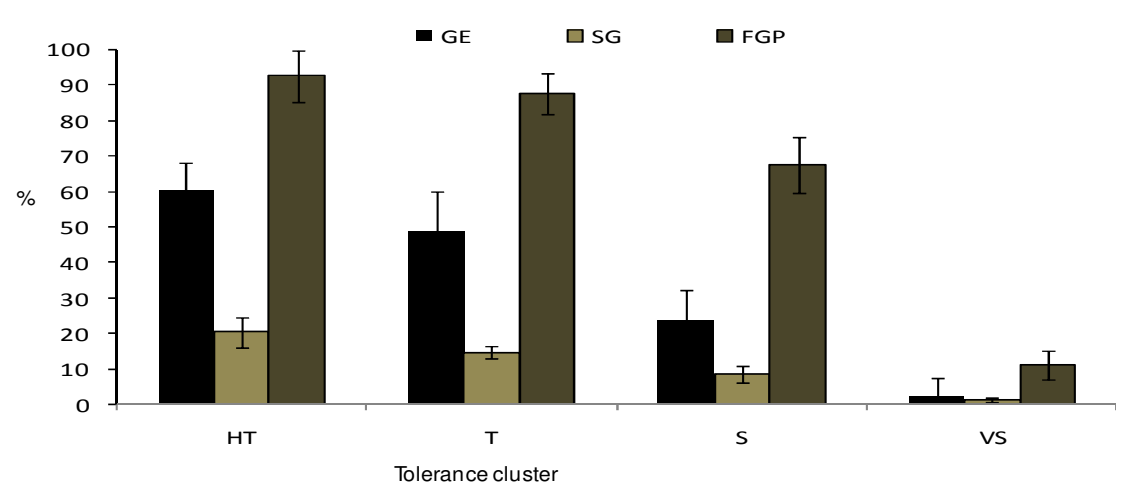

Fig. 2. Germination Energy (GE), Speed of Germination (SG) and Final Germination percentage (FGP) for varieties in different clusters based on the salt tolerance level at $24 \mathrm{dSm}^{-1}$.

\section{Germination Energy (GE)}

Germination Energy (GE) is defined as the present of seeds germinated during a period of time. Germination energy was observed at four days after soaking of seeds. Varietal differences in GE were significant at $24 \mathrm{dSm}^{-1}$ (Fig. 3). 


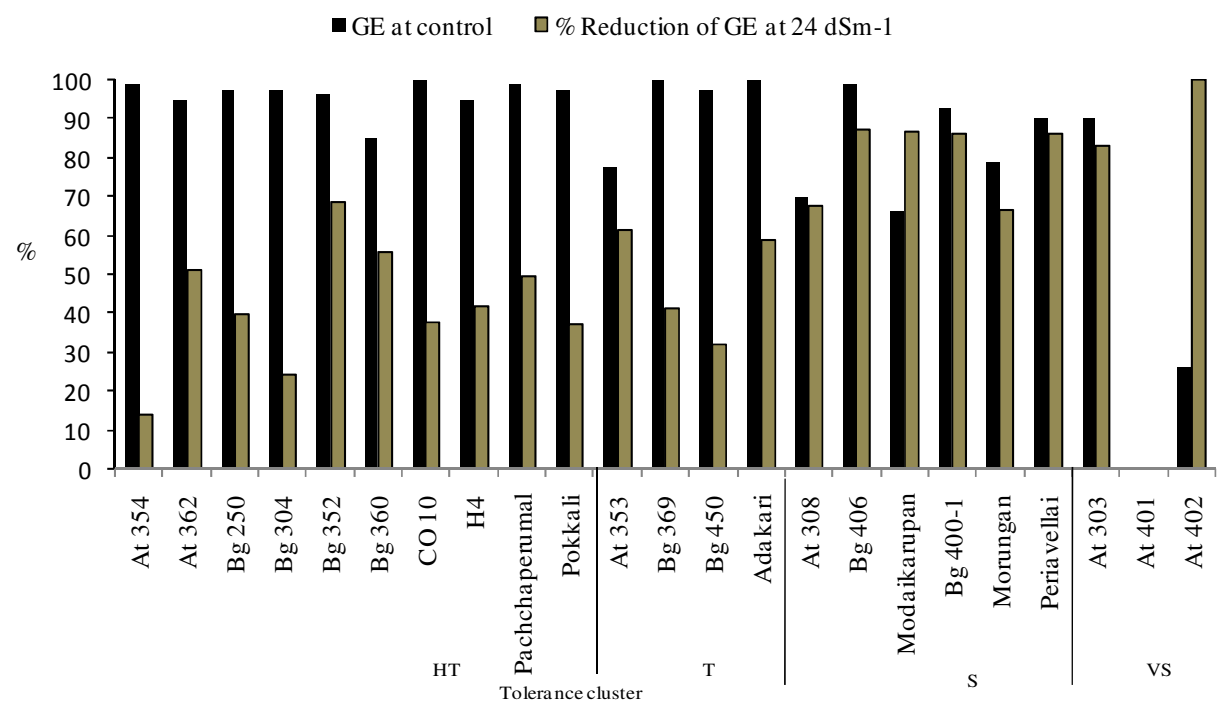

Fig. 3. Germination Energy (GE) of varieties at control $\left(0 \mathrm{dSm}^{-1}\right)$ and \% reduction of GE over control at $24 \mathrm{dSm}^{-1}$ with their tolerance

The lowest $\%$ reduction in germination energy was observed in varieties in highly tolerant cluster and the highest was in varieties in very sensitive cluster except At $362, \mathrm{Bg} 352$ and Bg 360 in highly tolerant cluster. Within the cultivated varieties in Jaffna, variety Bg 304 showed the lowest (24) \% reduction in GE which was in the high tolerant cluster. Variety At 402 showed the highest (100) \% reduction in GE which was in the very sensitive cluster. The variation in GE among the varieties may be due to the variation of osmotic effect of varieties to absorb water due to presence of salt. The seeds of salt-tolerant species had lower osmotic potentials, allowing them to absorb water from the environment. Rafiq et al., (2006) stated that the salt concentration completely inhibits germination at higher levels and reduces imbibition of water because of lowered osmotic potentials of the medium and causes changes in metabolic activity. Folkard and Wopereis (2001) reported that, in rice, salinity delayed germination with increasing salt stress. Size of seeds and thickness of seed coat may also influence the germination energy of seeds. If size of seed is smaller low reserves are available to induce germination and if seed coat is thick it takes long time to exert embryo out. In addition, tolerance is due to morphological characteristics in the plant. When considering the varieties grown in Jaffna, Pachchaperumal, H4, Bg 360, Bg 352, Periavellai, Morungan, Adakari, CO 10 had high Final Germination percentage (FGP) but low GE \% and the seeds from most of these varieties germinated after 4 days. The varieties with high GE $\%$ at high salinity level obviously get higher competitive advantages than the varieties having lower GE \% value for capturing environmental and edaphic resources.

\section{Speed of Germination (SG)}

Seed germination is a complex physiological process which would be affected by different salt concentrations. The speed of germination (SG) decreased as the salinity level increased 
and the significant difference in speed of germination was found between tested varieties at $24 \mathrm{dSm}^{-1}$ (Fig. 4).

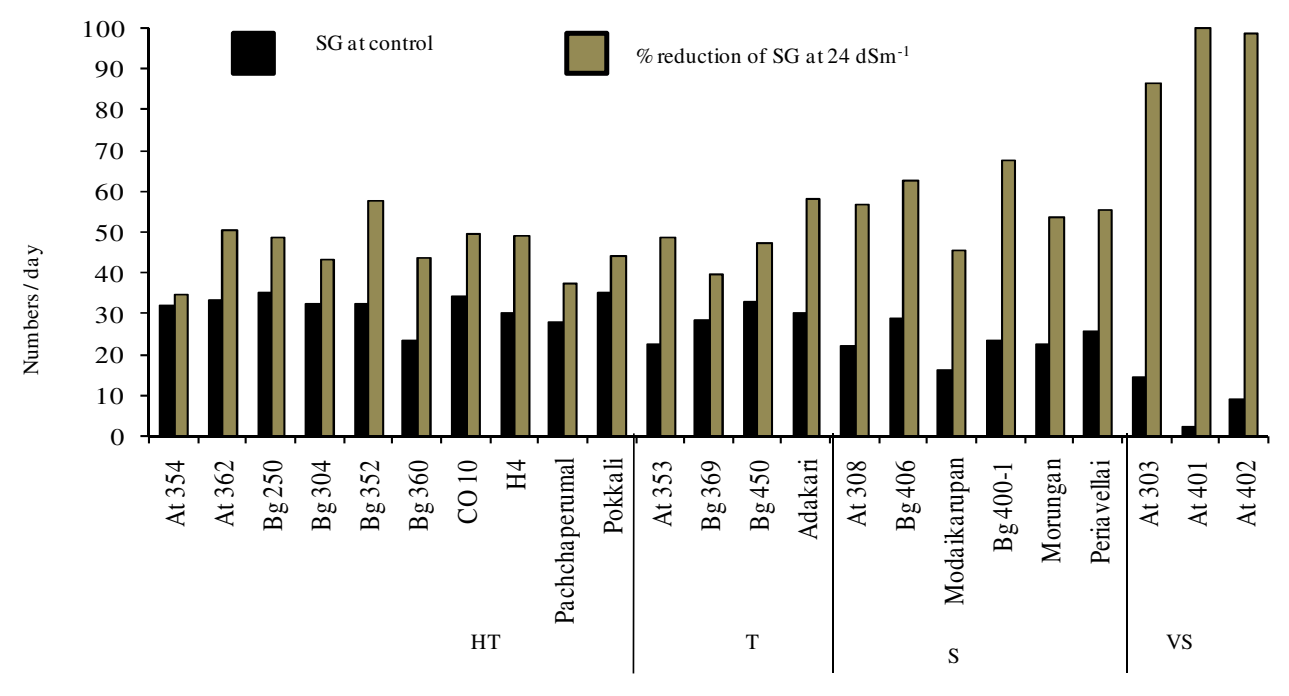

Tolerance cluster

Fig. 4. Speed of Germination (SG) of varieties at control and \% reduction of SG over control at $24 \mathrm{dSm}^{-1}$ with their tolerance.

Within the cultivated varieties in Jaffna, Pachchaperumal showed the lowest \% (37.6 \%) reduction of SG which was in highly tolerant cluster and variety At 402 showed the highest $\%$ reduction $(98.7 \%)$ which was in very sensitive cluster.

The reason for the reduction in speed of germination at high salt level $\left(24 \mathrm{dSm}^{-1)}\right.$ is due to osmotic stress outside the root causing changes in cell-water relations. The osmotic effect initially reduces the ability of the plant to absorb water. If availability of water reduces to seeds, it would affect the physiological activities in seeds and delay the germination processes. If the water potential of the imbibition medium is reduced, germination will be delayed or prevented. Heenan et al., (1988) also found that the reduction in speed of germination due to osmotic stress at high salt levels. In addition to osmotic effect, toxic effects due to sodium ions also influence the speed of seed germination. This result is similar to Aliakbar \& Kobra, (2008) that toxic effects of salts change the enzymatic activity and hormonal balance of seeds which would reduce the speed of germination.

\section{Final Germination Percentage (FGP)}

Germination was completely inhibited for all the varieties at $45 \mathrm{dSm}^{-1}$ salt level. However, there was a significant difference among varieties in FGP at $24 \mathrm{dsm}^{-1}$ (Fig. 5). 


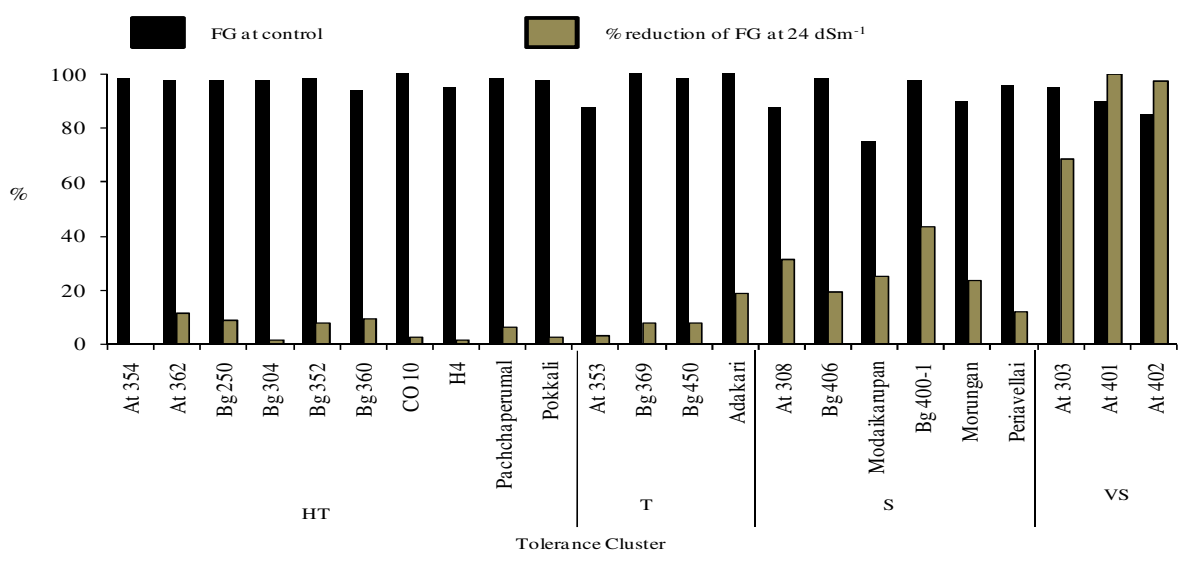

Fig. 5. Final Germination Percentage (FGP) of varieties at control and $\%$ reduction of FGP over control at $24 \mathrm{dSm}^{-1}$ with their tolerance.

Among the varieties grown in Jaffna, Bg 304 had the lowest reduction \% of FGP $(1.28 \%)$ while the variety At 402 showed the highest \% reduction (96.4\%) of FGP. Also Rice varieties $\mathrm{CO} 10$, Pachchaperumal and $\mathrm{H} 4$ in highly tolerant cluster had lower \% reduction of FGP of 2.5, 1.32 and 6.33 respectively.

Final germination percentages (FGP) of all tested varieties at EC levels, 0, 4, 8, 12 and 24 $\mathrm{dSm}^{-1}$ were given in Fig. 6 .

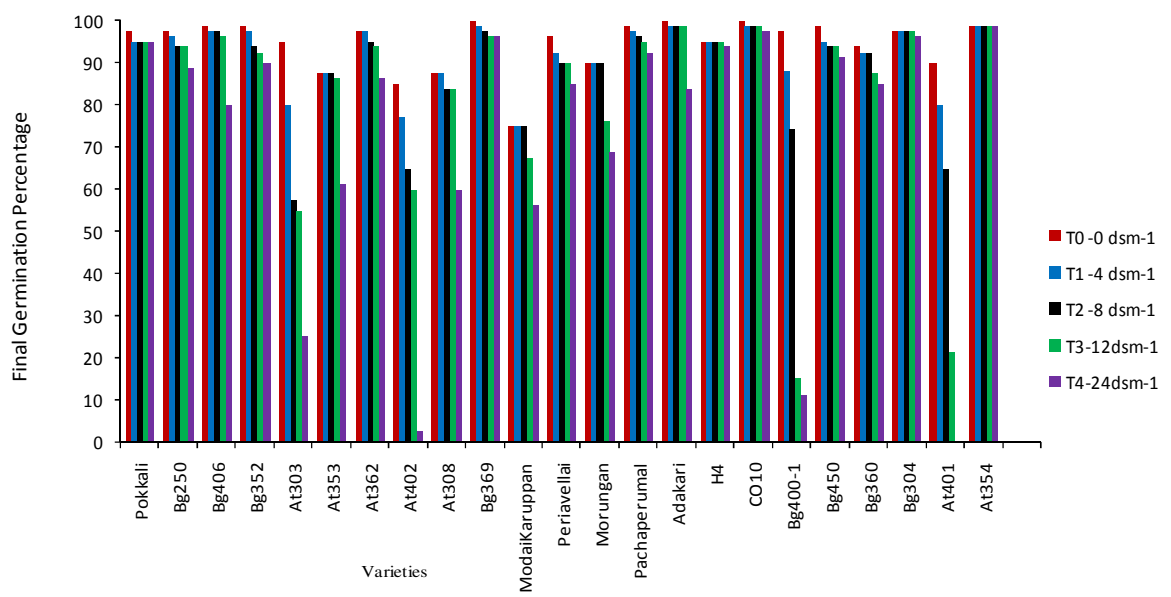

Fig. 6. Final germination percentages of all tested varieties at EC levels of 0,4, 8, 12 and $24 \mathrm{dSm}^{-1}$.

Germination percentages were inversely related to salt concentration level. High salt level of $24 \mathrm{dSm}^{-1}$ affects the imbibition of water to seeds which would reduce the physiological activities within the seed during germination. Variability in salinity tolerance among rice 
varieties at germination stage have been reported by many researchers (Subasinghe et al., 2007; Hakim et al., 2010; Anbumalarmathi \& Preeti Mehta, 2013). Seed germination was not significantly affected up to $16.3 \mathrm{dSm}^{-1}$, but was severely inhibited when salinity increased to $22 \mathrm{dSm}^{-1}$ (Heenan et al., 1988). Akbar \& Ponnamperuma (1982) stated that the osmotic effect due to salinity was the main inhibitory factor that reduced germination. Toxic effect due to sodium also inhibits germination processes. Neumann (1997) stated that high intracellular concentrations of both $\mathrm{Na}^{+}$and $\mathrm{Cl}^{-}$can inhibit the metabolism of dividing and expanding cells which in turn retards germination and even leading to seed death. Abeysiriwardena, (2004) reported that the germination percent was reduced with increasing salinity and tolerant cultivars recorded higher germination percent than that of the sensitive cultivars.

\section{Average Root Length (ARL)}

The average root length (ARL) of all the rice varieties was decreased with increased salt level of 4, 8, 12 and $24 \mathrm{dSm}^{-1}$ and a significant difference in the ARL was observed at salt level of $24 \mathrm{dSm}^{-1}$ (Fig. 7).

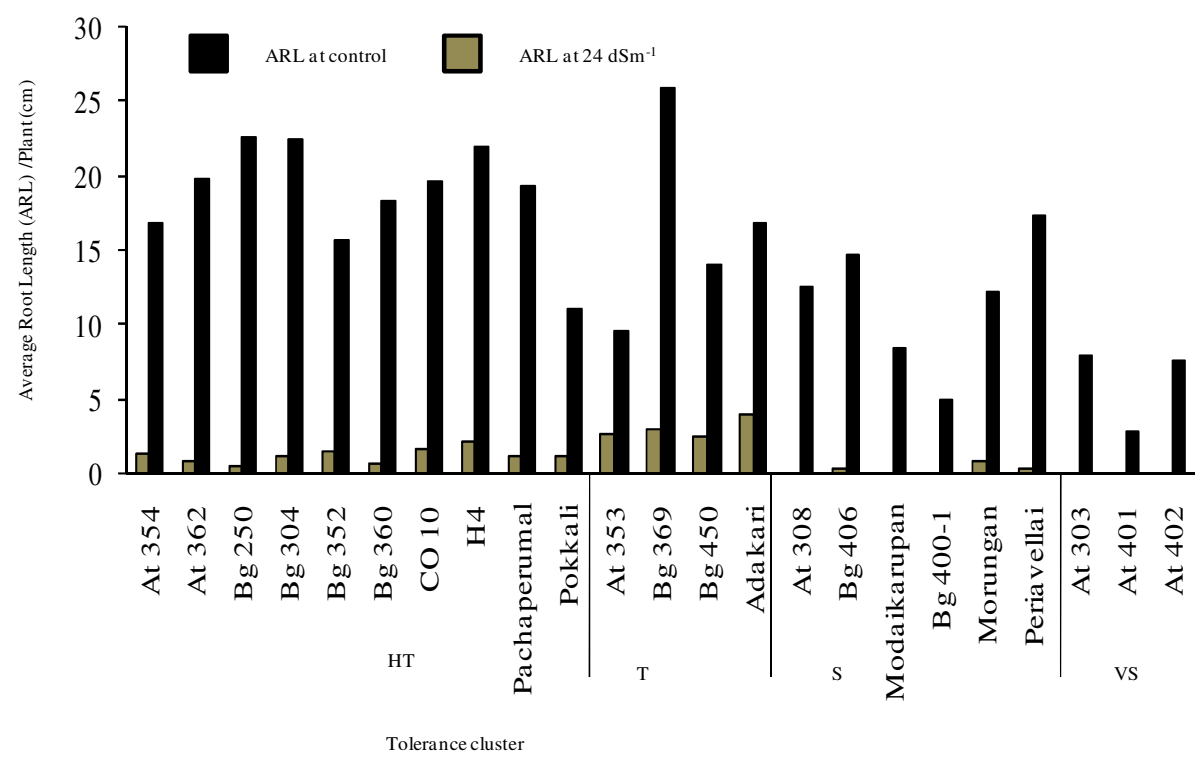

Fig. 7. Average Root Length (ARL) of rice varieties under control and ARL at 24 $\mathrm{dSm}^{-1}$ with their tolerance.

Among the cultivated rice varieties of Jaffna, varieties such as At $362, \mathrm{Bg} 250, \mathrm{Bg} \mathrm{304,} \mathrm{Bg}$ 352, Bg 360, CO 10, H4 and Pachaperumal categorized in highly tolerant cluster had $>15$ $\mathrm{cm}$ ARL at control. Varieties Adakari and At 353 in tolerant cluster showed $16.84 \mathrm{~cm}$ and $9.56 \mathrm{~cm}$ ARL respectively. The gradual decrease in root length with increase in salinity might be due to inhibitory effect of $\mathrm{NaCl}$ to root elongation by restricting cell division and expansion of root. The same results in root length reduction with salinity also obtained by Rahman et al., (2001). 


\section{Average Plumule (Coleoptile) Length (APL)}

Average Plumule Length (APL) of all the tested rice varieties was declined at $24 \mathrm{dSm}^{-1}$ (Fig. 8).

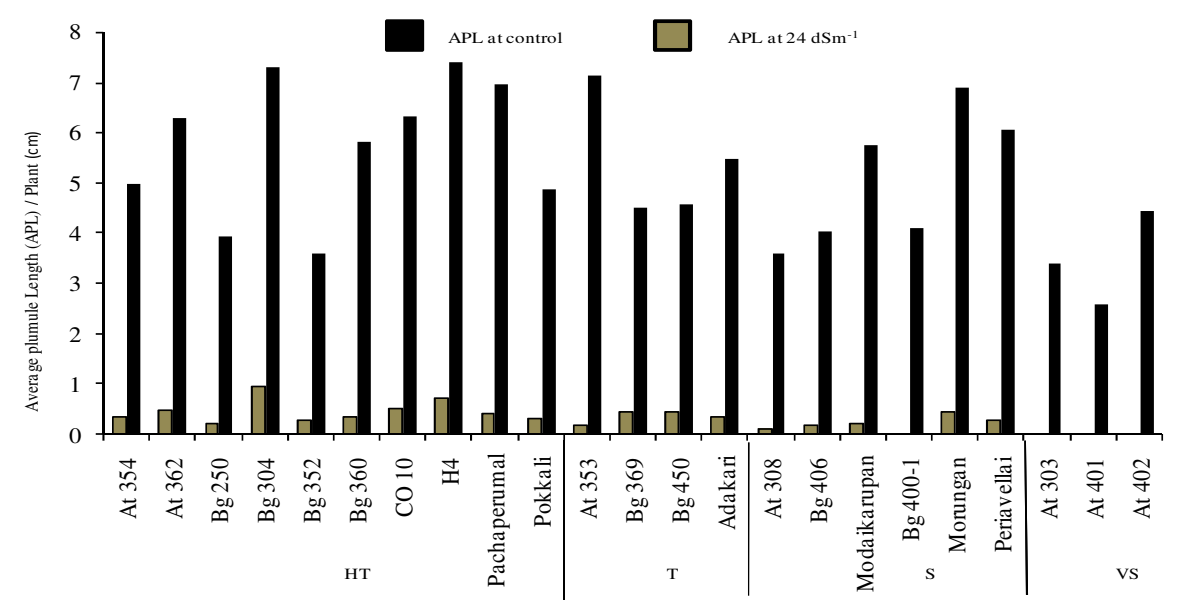

Tolerence cluster

Fig. 8. Average Plumule Length (APL) of rice varieties under control and APL at 24 $\mathrm{dSm}^{-1}$ with their tolerance.

All the varieties in different clusters showed the greater reduction in APL at $24 \mathrm{dSm}^{-1}$ except the variety $\mathrm{Bg} 304$ in highly tolerant cluster. Within cultivated varieties in Jaffna, varieties $\mathrm{Bg} 250$ and $\mathrm{Bg} 352$ showed lower APL of $0.19 \mathrm{~cm}$ and $0.28 \mathrm{~cm}$ respectively under highly tolerant cluster. Variety At 353 had the lowest APL of $0.18 \mathrm{~cm}$ in tolerant cluster.

The correlation analysis between variables GE, SG, FGP, ARL and APL was done at EC level of $24 \mathrm{dSm}^{-1}$ (Table 4).

Table 4. Pearson correlation matrix for tested variables.

\begin{tabular}{lllll}
\hline \multirow{3}{*}{ GE } & SG & FGP & ARL & APL \\
& 0.91 & 0.78 & 0.47 & 0.73 \\
SG & $\mathrm{p}<.0001$ & $\mathrm{p}<.0001$ & $\mathrm{P}=0.0226$ & $\mathrm{p}<.0001$ \\
& & 0.92 & 0.47 & 0.69 \\
FGP & $\mathrm{p}<.0001$ & $\mathrm{P}=0.0222$ & $\mathrm{P}=0.0002$ \\
& & 0.52 & 0.73 \\
ARL & & $\mathrm{P}=0.0095$ & $\mathrm{p}<.0001$ \\
& & & 0.047 \\
\hline
\end{tabular}

There are significant correlations between SG and GE, FGP and GE, FGP and SG, APL and GE, APL and FGP with in tested varieties.

Root length (40 plants), Coleoptile/Plumule length (40 plants), speed of germination, germination energy and final germination percentage at EC levels of $0,4,8,12$ and $24 \mathrm{dSm}^{-1}$ 
for some selected rice varieties from each cluster were given below (Fig. 9,10,11,12,13 and $14)$.

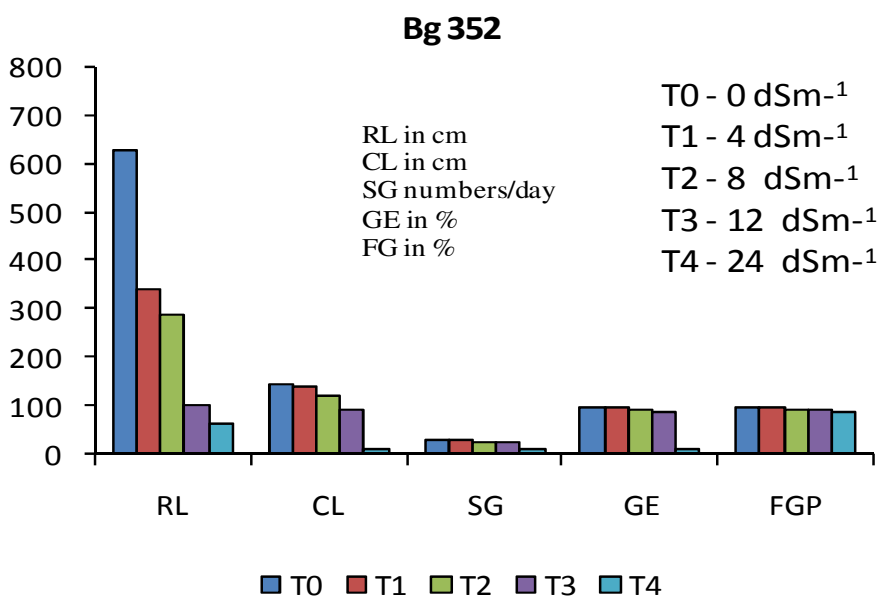

Fig. 9. Root length, plumule length (Coleoptile), speed of germination, germination energy, final germination percentage at EC levels of $0,4,8,12$ and $24 \mathrm{dSm}^{-1}$ for Bg 352.

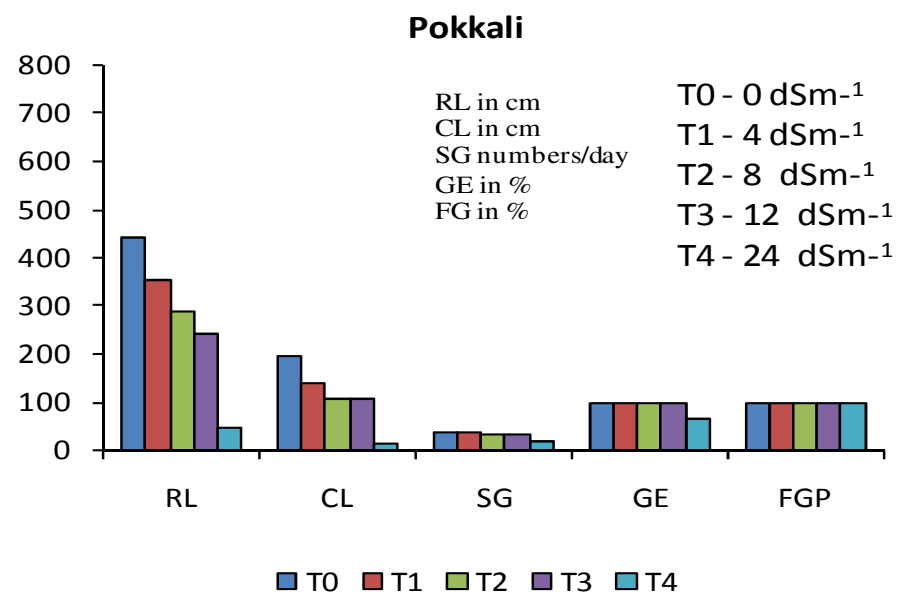

Fig. 10. Root length, plumule length (Coleoptile), speed of germination, germination energy, final germination percentage at EC levels of $0,4,8,12$ and $24 \mathrm{dSm}^{-1}$ for Pokkali. 


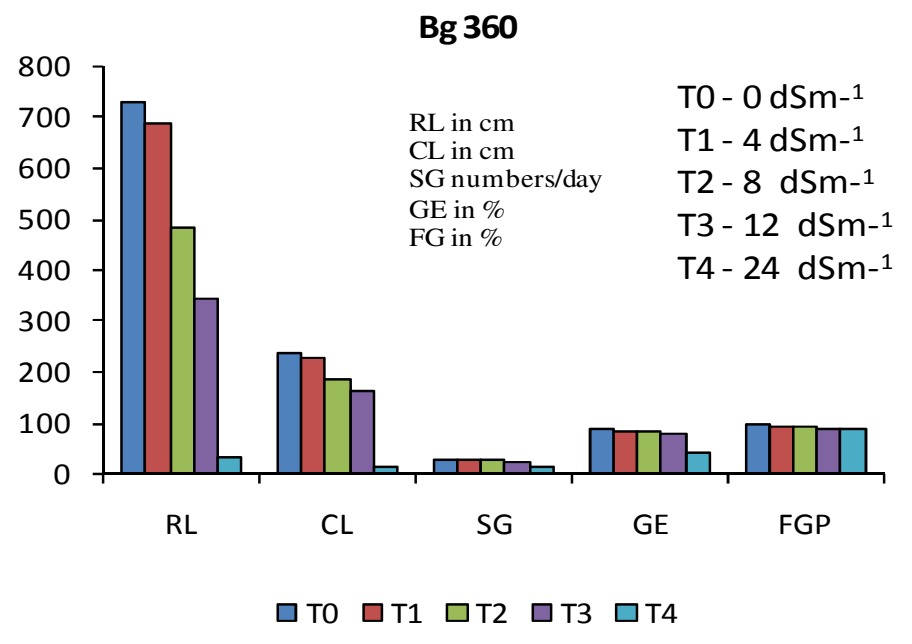

Fig. 11. Root length, plumule length (Coleoptile), speed of germination, germination energy, final germination percentage at EC levels of $0,4,8,12$ and $24 \mathrm{dSm}^{-1}$ for Bg 360 .

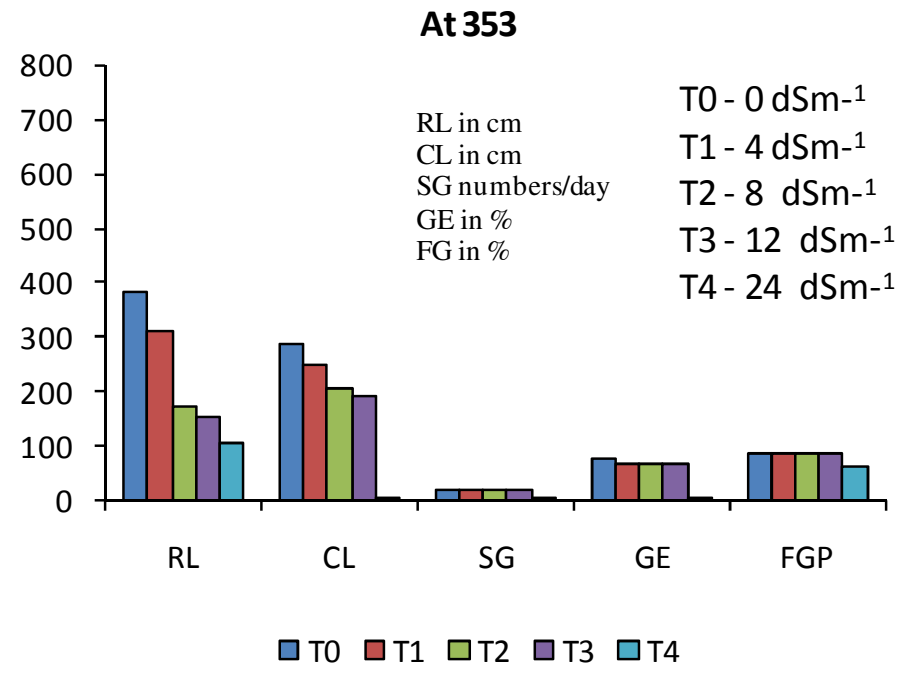

Fig. 12. Root length, plumule length (Coleoptile), speed of germination, germination energy, final germination percentage at EC levels of $0,4,8,12$ and $24 \mathrm{dSm}^{-1}$ for At 353. 


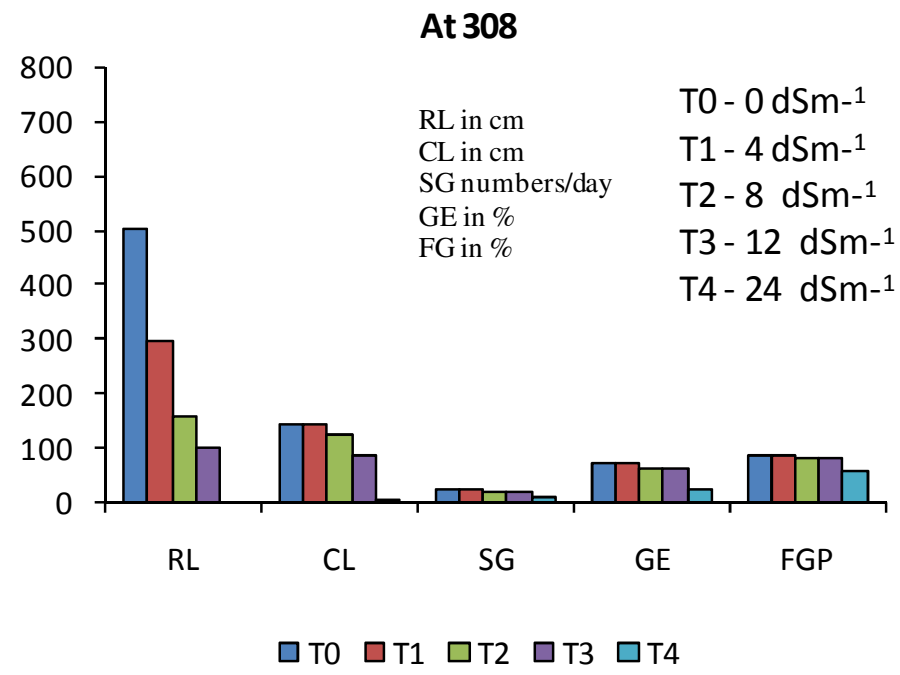

Fig. 13. Root length, plumule length (Coleoptile), speed of germination, germination energy, final germination percentage at EC levels of $0,4,8,12$ and $24 \mathrm{dSm}^{-1}$ for At 308.

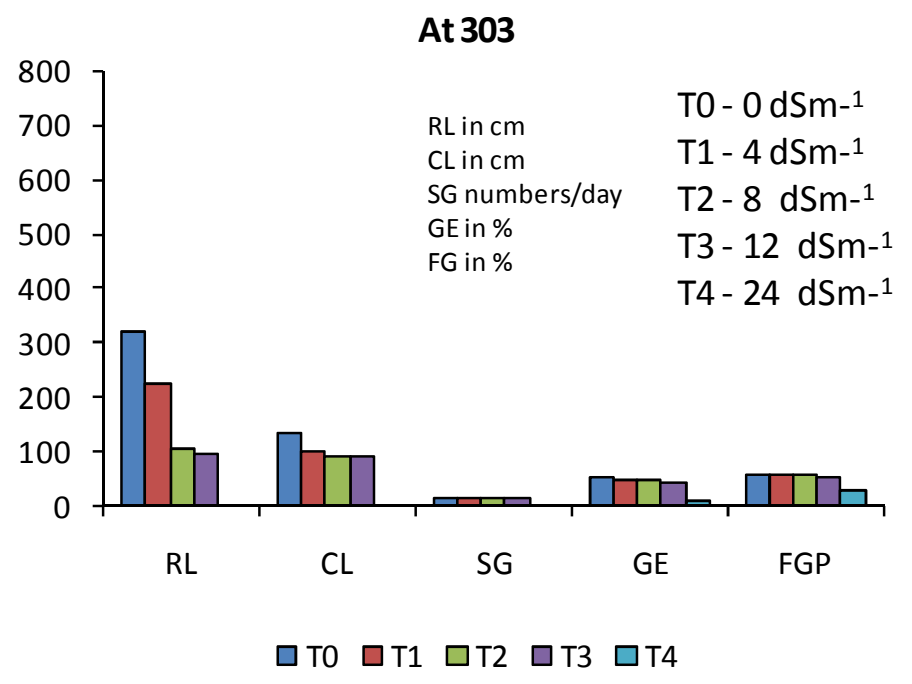

Fig. 14. Root length, plumule length (Coleoptile), speed of germination, germination energy, final germination percentage at EC levels of $0,4,8,12$ and $24 \mathrm{dSm}^{-1}$ for At 303. 
The growth reduction occurs quickly after exposure to salinity. This response is due to the osmotic changes outside the root causing changes in cell-water relations. The osmotic effect initially reduces the ability of the plant to absorb water. During germination, root and plumule length of plants decreased with increased salt stress. Due to salt, cell elongation and to a lesser extent of cell division, are reduced leading to lower rates of leaf and root growth. The considerable reduction was observed on plumule length compared to root length. Reductions in cell division and elongation translate into slower leaf appearance and size. These results are in agreement with Ahmed et al., (2012) that, the seedling growth was drastically decreased at higher salinity level and the impact was remarkable on shoot compared to the root growth. Fricke et al., (2006) found that in vegetative plants, salt stress causes reduced cell turgor and depressed rates of root and leaf elongation. Salinity decreases final germination percentage, speed of germination and led to reduction in shoot and root length and dry weight in all varieties and the magnitude of reduction increased with increasing salinity stress (Hakim et al., 2010).

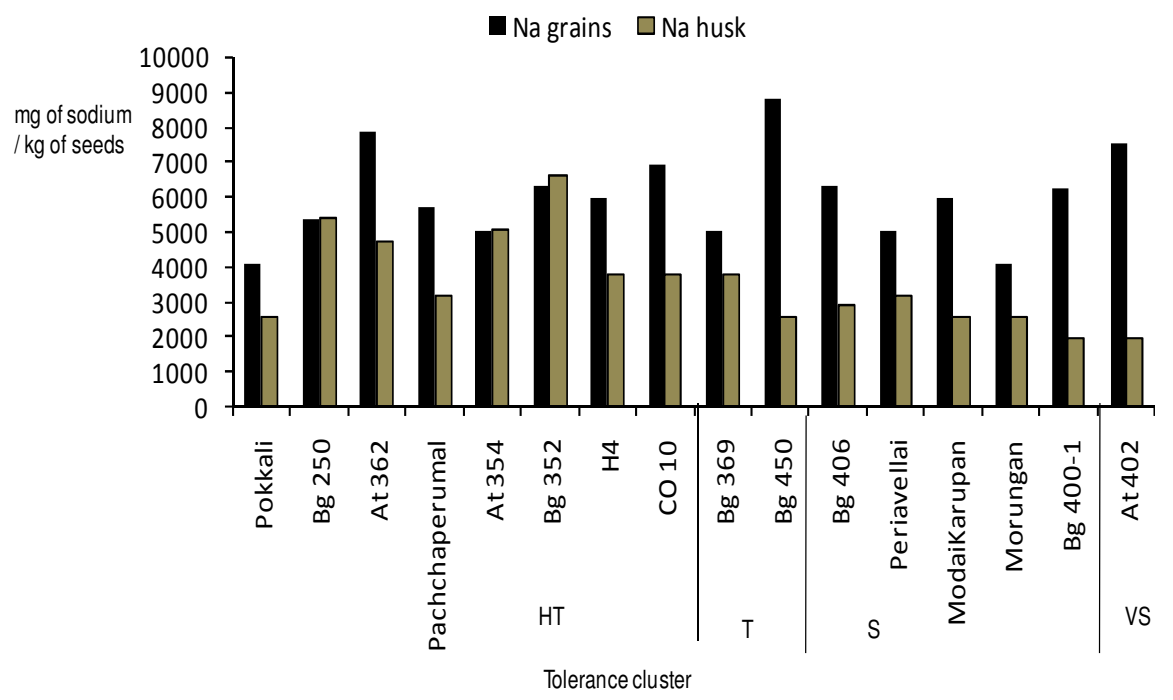

Fig. 15. Sodium concentration in the endosperm (grain) and husk of selected rice varieties within tolerance cluster at $24 \mathrm{dSm}^{-1}$.

Varieties having low sodium concentration in the grain showed high tolerance to salt due to less inhibitory effect by sodium for water absorption for germination and vice versa (Fig. 15). Varieties categorized under high tolerance and tolerance clusters showed lower sodium concentrations in grains compared to sensitive and very sensitive varieties except for varieties At 362, Bg 352, CO 10 and $\mathrm{Bg} 450$. These varieties may be having special genetic makeup in seeds which may helps to induce good germination even under high sodium content in grains. In addition to osmotic effect, tolerance of a crop variety to salt stress is associated with its ability to restrict uptake of potentially toxic $\mathrm{Na}^{+}$ion . The salt tolerant varieties maintained lower $\mathrm{Na}$ concentrations under high salt concentration and the sensitive rice varieties were unable to effectively prevent accumulation of $\mathrm{Na}^{+}$.

\section{CONCLUSIONS}


Among the rice varieties cultivated in Jaffna, Pachchaperumal, At 362, Bg 250, Bg 352, H4, $\mathrm{Bg} 304, \mathrm{Bg} 360$ and CO 10 were highly tolerant to salt by having higher germination energy, speed of germination, final germination percentage, average root length and average plumule length. Varieties At 353 and Adakari were categorized under tolerant to salt even though having higher average root length and average plumule length; germination energy, speed of germination and final germination percentage were lower compared to highly tolerant varieties. Sodium concentration in grains was also lower in these two groups except for At 362 , Bg 352, CO 10 and Bg 450 compared to very sensitive group. These varieties might be having specific morphological and physiological characteristics to show tolerance to salt. Varieties Morungan, Periavellai, At 308 and Modaikarupan had higher average root length and average plumule length while germination energy, speed of germination and final germination percentage of varieties were lower compared to tolerant varieties which were grouped under salt sensitive group. Varieties At 402 and At 303 were very sensitive to salt at $24 \mathrm{dSm}^{-1}$ during their germination stage by having very lower levels of all characters tested except for sodium concentration in grains.

\section{ACKNOWLEDGEMENTS}

Support provided by Head, Department of Agronomy, Dean, Faculty of Agriculture and Vice Chancellor, University of Jaffna to read for $\mathrm{PhD}$, the financial support provided by HETC project (JFN/O-Agri/N6), the facilities provided for conducting the research at Department of Crop Science, Faculty of Agriculture, University of Peradeniya and technical support provided by B.G.G. Wijesooriya are gratefully appreciated.

\section{REFERENCES}

Abeysiriwardena, D.S.De Z. (2004). A simple screening technique for salinity tolerance in rice: germination rate under stress. International Rice Research Notes. 29(2), 78-79.

Ahmed, M. E. Khawla, E. M. Elshiekh, A.I. and Nagla, N. S. (2012). Impact of salinity on seed germination and early seedling growth of three sorghum (Sorghum biolor L. Moench) cultivars. Science and Technology. 2(2), 16-20.

Akbar, M. and Ponnamperuma, F.M. (1982). Saline soils of South and Southeast Asia as potential rice land. In rice research strategies for the future. IRRI, pp. 265-281.

Aliakbar, M.M. and Kobra, M. (2008). Salt Stress Effects on Respiration and Growth of Germinated Seeds of Different Wheat (Triticum aestivum L.) Cultivars. World Journal of Agricultural Sciences 4(3), 351-358.

Anbumalarmathi, J. and Preeti Mehta (2013). Effect of Salt Stress on Germination of indica Rice Varieties, www.ejarr.com/Volumes/Vol6, pp 1-6.

Boyer, J.S. (1982). Plant productivity and environment. Science. 218, pp. 443-448.

Chowdhury, M.A.M. and Bowling, D.J.F. (1995). A rapid method for screening rice plants for salt tolerance. Tropical Agricultural research. 7 . 
Dissanayake, P.K. and Wijeratne, A.W. (2006). Development of a varietial screening procedure for salt tolerance of rice (Oryza sativa I.) varieties at germination stage. The Journal of Agricultural Sciences, 2(1).

Fricke, W. Akhiyarova, G. and Wei, W.X. (2006). The short-term growth response to salt of the developing barley leaf. Journal of Experimental Botany. 57, 1079-1095.

Folkard, A. and Wopereis, M.C.S. (2001). Responses of field-grown irrigated rice cultivars to varying levels of flood water salinity in a semi-arid environment. Field Crop Res. 70, 127 137.

Hakim, M.A. Juraimi, A.S. Begum, M. Hanafi, M.M. Ismail, M.R. and Selamat, A. (2010). Effect of salt stress and germination and early seedling growth of rice (Oryza sativa L.).African J.Biotech. 9, pp. 1911-1918.

Handawela, J. (1982). A study on inland salinity in Mahaweli H area. Krushie. Quarterly Tech. Bull. Researchers, Extension Workers and Trainers in Agriculture, 5(1), 5-14.

Heenan, D.P. Lewin, L.G. and McCaffery, D.W. (1988). Salinity tolerance in rice varieties at different growth stages. Aust. J. Exp. Agric. 28, 343-349.

IRRI. (1989). Towards 2000 and beyond. IRRI. Manila. Philippines.

Maas, E.V. (1986). Salt tolerance of plants. Applied Agricultural Research, 1, pp. 12-26.

Maranon, T. Garc, A.L. and Troncoso, A. (1989). Salinity and germination of annual Melilotus from the Guadalquivir delta (SW Spain). Plant and Soil, 119, 223-228.

Neumann, P. (1997). Salinity resistance and plant growth revisited. Plant Cell and Environment. 20, 1193-1198.

Rafiq, S. Iqbal, T. Hameed, A. Zulfiqar Ali, R. and Rafiq, N. (2006). "Morphobiochemical analysis of salinity stress response of wheat," Pakistan Journal of Botany, 38(5), pp. 17591767.

Rahman, M.S. Miyake, H. and Takeoka, Y. (2001). Effect of sodium chloride salinity on seed germination growth of rice (Oryza sativa L): Parkistan Journal of Biological Sciences 4(3), 351-355.

Rajadurai, S (2003). Rainfed rice cultivation in Jaffna district. Smart prints, Jaffna. pp 1-5.

Ruan, S. Xue, Q. and Thlkowska, K. (2002). Effect of seed priming on germination and health of rice (Oryza sativa L.) seeds. Seed Sci. Technol. 30, 451-458.

Sirisena, D.N. and Herath, H.M.A. (2009). Productivity enhancement in saline paddy fields in Angiththamkulam Yaya in Sri Lanka: Proceedings of the $9^{\text {th }}$ International Conference of East and Southeast Asia Federation of Soil Science Societies. Seoul, Korea. pp. 507-508. 
Subasinghe, A. Nissanka, N.A.A.S.P. and Weerakoon, W.M.W. (2007). Identification of salt tolerant rice varieties at the seed germination stage and its relationship to seed husk thickness and ion absorption. Tropical Agricultural Research, 19, 219-228.

World Bank Report, (2012). [Accessed on 22.06.2013]. Available at http://www.tradingeconomics.com/SriLanka/population-growth-annual-percent-wbdata.html. 